\title{
Studi Katalitik Herbal Rebusan Daun Salam sebagai Bahan Aktif Menurunkan Tekanan Darah Tinggi
}

\author{
Novia Anggraini*1 \\ ${ }^{1}$ Pendidikan Kimia,FMIPA, Universitas Negeri Padang, \\ Indonesia \\ *E-mail : noviaanggraini1903@gmail.com
}

\begin{abstract}
Abstrak. Studi ini bertujuan untuk membuat rebusan pada tumbuhan daun salam untuk menurunkan tekanan darah tinggi atau hipertensi. Metode yang digunakan adalah eksperimen dan uji aktivitas katalitik secara langsung. Tahapan pertama dilakukan dengan pembuatan rebusan daun salam. Uji aktivitas langsung dengan variasi volume air ekstrak daun salam yang diminum selama tujuh hari. Hasil eksperimen membuktikan bahwa rebusan daun salam dapat menurunkan tekanan darah tinggi. Kondisi optimal terhadap ekstrak daun salam tercapai pada $90 \mathrm{ml}$ dengan tekanan darah $130 \mathrm{mmHg}$. Diduga penurunan tekanan darah ini karena aktivitas katalitik rebusan daun salam terhadap penurunan kolesterol, sehingga flavonoid, saponin dan tannin dapat digunakan sebagai penurunan tekanan darah tinggi atau hipertensi.
\end{abstract}

Keywords: katalitik, rebusan, daun salam, tekanan darah tinggi, flavonoid, saponin, tanin

\section{Pendahuluan}

Reaksi $^{[1-25]}$ katalitik adalah reaksi kimia $^{[26-35]}$ yang melibatkan katalis dalam reaksinya. Reaksi kimia yang melibatkan katalis ${ }^{[36-40]}$ dalam reaksinya dapat mempercepat terjadinya reaksi namun katalis tidak ikut bereaksi. Suatu reaksi sangat penting dalam kehidupan. Jika suatu reaksi kimia ${ }^{[41-48]}$ tidak berjalan sesuai maka akan terjadi pembusukan ${ }^{[49-52]}$. Reaksi kimia juga terjadi ditubuh ${ }^{[53-57]}$ manusia $^{[58-59]}$, hewan ${ }^{[60]}$ dan tumbuhan, mulai dari reaksi kimia yang sederhana sampai reaksi kimia yang kompleks. reaksi kimia dapat terjadi cepat atau lambat sesuai reaktan yang direaksikan. Jika suatu reaksi kimia lambat maka dapat ditambahkan katalis ${ }^{[61]}$.

Reaksi katalitik dapat berjalan secara reversible dan irrversibel. Reaksi yang mengalami reversible dapat berbalik arah, sedangkan reaksi irreversible tidak dapat berbalik arah. Adapun factor yang menjadi suatu reaksi dapat mengalami reversible, diantaranya reaktan yang digunakan sesuai dan spesifik ${ }^{[62-65]}$. Contoh nya reaksi kesetimbangan. Namun, kebanyakan reaksi kimia jarang yang mengalami reaksi reversible, karena suatu reaksi kimia ${ }^{[66-67]}$ akan mengalami perubahan kimia. Ciri-ciri perubahan kimia yaitu tidak dapat kembali ke bentuk semula, adanya perubahan ${ }^{[68-70]}$ suhu $^{[71-72]}$, perubahan $\mathrm{pH}$, perubahn warna $^{[73]}$, menghasilkan gas ${ }^{[74-76]}$, dan terbentuk endapan ${ }^{[77-79]}$. 
Dalam kehidupan kita sehari-hari banyak ditemukan katalis, baik katalis alami $^{[80]}$ maupun katalis buatan yang terdapat di laboratorium ${ }^{[81-82]}$ kimia. Katalis $^{[83]}$ alami ${ }^{[84-87]}$ biasanya bersumber dari tumbuhan ${ }^{[88]}$ dan buah-buahan ${ }^{[89-90)]}$ yang mengandung zat tertentu untuk reaksi pada tubuh ${ }^{[91-93]}$. Katalis dari tumbuhan ${ }^{[94-96]}$ biasanya digunakan pada bagian daun ${ }^{[97-100]}$ atau akarnya, contoh nya daun salam ${ }^{[101-102]}$, daun $\operatorname{sirsak}^{[103]}$,akar ${ }^{[104]}$ empedu tanah dan yang lainnya yang memiliki khasiat ${ }^{[105-107]}$ masing-masing. Untuk katalis yang berasal dari buah seperti buah nanas ${ }^{[108]}$,tomat ${ }^{[109]}$, buah kismis dan lain sebagainya. Setiap buah yang mengandung zat tertentu yang digunakan sebagai katalis memiliki peranan yang berbeda untuk mengatasi penyakit dan meningkatkan suatu reaksi pada ubuh manusia. Sehingga zat yang berfungsi sebagai katalitik ${ }^{[110]}$ memiliki peran yang spesifik $^{[111-113]}$ dan khusus.

Daun salam pada tubuh dapat merangsang suatu reaksi karena pada daun salam memiliki suatu zat yang bersifat katalitik. Sehingga daun salam banyak dimanfaatkan oleh masyarakat Indonesia. Daun salam banyak ditemui di sekitar kita, terutama daerah tropis seperti Indonesia dan sangat mudah ditemui dipasaran. Fungsi daun salam sebagai tumbuhan yang mengandung zat sebagai katalis maka daun ini tidak asing lagi. Daun salam tubuh sebagai tumbuhan berkayu dan memiliki daun yang rimbun serta memiliki buah yang enak untuk dimakan.

Daun salam sangat banyak digunakan oleh masyarakat Indonesia karena banyak mengandung manfaat. Manfaat daun salam yaitu sebagai obat ${ }^{[14-117]}$, kemudian juga umum digunakan sebagai bumbu pelengkap pada masakan, terutama masakan tradisional Minangkabau. Di Sumatera Barat daun salam sangat berperan penting dalam masakan, terutama gulai dan randang. Daun salam dapat memberi cita rasa yang khas dari sebuah masakan, sehingga dapat membedakan masakan Minangkabau dengan daerah lainnya. Hal yang paling dicari dari daun salam ketika dijadikan bumbu masakan adalah wangi dan khasiatnya. Apabila daun salam tidak ada pada masakan Minang maka akan terasa berbeda, walaupun diganti dengan bumbu racikan yang praktis karena sesuatu yang alami tidak akan bisa digantikan dengan yang racikan dan mengandung zat kimia.

Selain sebagai bumbu pada masakan, daun salam dipercayai dapat digunakan sebagai obat tradisional. Daun salam memiliki nama latin Syzygium polyanthum ${ }^{[18]}$ Manfaatnya sebagai obat yaitu dapat menurunkan tekanan darah tinggi dari ekstrak air rebusannya. Daun salam penting dalam kehidupan karena manfaat nya yang sangat besar dan mudahnya ditemukan. Dengan menggunakan daun salam sebagai obat penurun tekanan darah tinggi, orang-orang tiak perlu langsung menggunakan obat kimia yang dapat menimbulkan efek samping pada tubuh. Reaksi yang terjadi pada orang yang memiliki tekanan darah tinggi akan langsung terasa ketika menggunakan daun salam ini, menurut pengalaman reaksi nya berlangsung cepat pada tubuh. Namun, setiap tubuh akan berbeda-beda dalam menerima suatu zat yang dianggap asing, bisa lansung diterima atau bisa tidak cocok ditandai dengan lambatnya bereaksi pada tubuh.

Daun salam sebagai obat tradisional banyak digunakan sampai sekarang. Orang zaman dahulu banyak menggunakannya sebagai obat penurun tekanan darah tinggi. Daun salam dapat direbus dan diminum air dari rebusan ${ }^{[119]}$ daunnya. Adaun senyawa-senyawa ${ }^{[120-125]}$ yang banyak terkandung dalam daun salam dapat yang mengobati tekanan darah tinggi atau hipertensi tersebut. Untuk itu tujuan dari paper ini adalah membuktikan apakah rebusan daun salam dapat menurunkan tekanan 
darah tinggi atau hipertensi ${ }^{[126]}$ pada seseorang. Berdasarkan informasi yang didapat dari orang tua, rebusan daun salam ini mampu menurunkan tekanan darah tinggi, sehingga daun salam sebagai obat tradisional tidak asing lagi dan banyak dikonsumsi sehari-hari oleh orang yang memiliki penyakit ${ }^{[127]}$ hipertensi. Kemudian pengolahan nya juga mudah dan cepat sehingga menjadi alternative ${ }^{[128-}$ 130]

\section{Metode}

\section{Alat dan Bahan}

Peralatan yang digunakan adalah: gelas (royalex), sendok (stainlesssteal), kompor (rinnai), panci (buterflay), iring (GM product). Bahan yang digunakan adalah dau salam yang diambil di Koto Malintang Sariak Laweh Kec. Akabiluru, air (aqua)

\section{Prosedur kerja}

\section{Penyiapan sampel}

Sampel diambil di Jorong Koto Malintang, Nagari Sariak Laweh, Kec. Akabiluru, Kab. 50 Kota. Sampel diambil sebanyak 30 lembar (10 gram), kemudian sampel dicuci hingga bersih

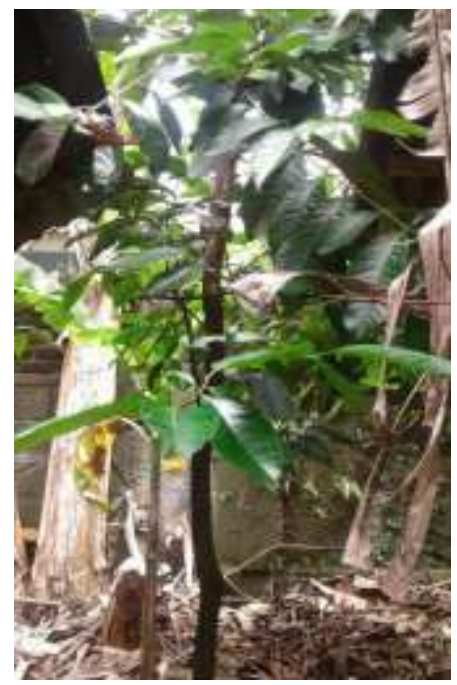

(a)

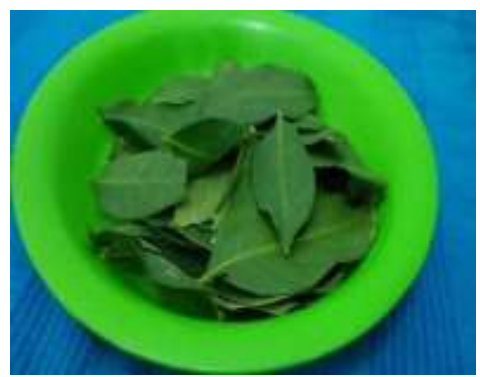

(c)

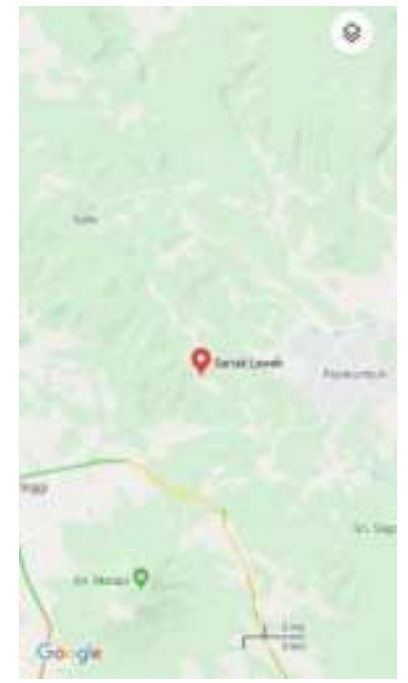

(b)

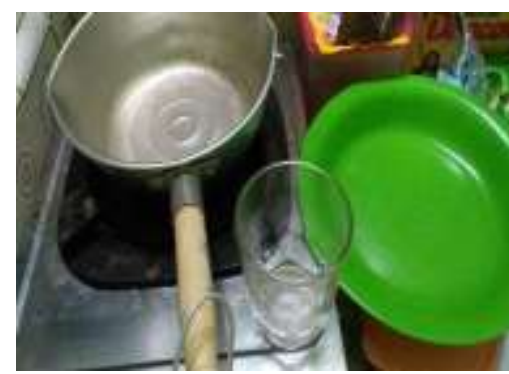

(d)

Gambar 1. Sampel bahan yang digunakan (a). Pohon daun salam, (b). Lokasi pengambilan sampel, (c). Daun yang sudah dipetik (30 helai), (d). Alat dan bahan pembuatan rebusan. 


\section{Pembuatan Air Rebusan}

Air rebusan daun salam dibuat denga cara direbus sebanyak 30 helai (10 gram) dan air mineral 2 gelas untuk ekstrak 1 gelas, kemudian direbus hingga air berkurang dan medidih sampai tersisa 1 gelas $(180 \mathrm{ml})$. Lalu dimasukkan ke dalam gelas.

\section{Pengujian Air Rebusan}

Rebusan yang telah jadi dicobkan ke orang yang memiliki darah tinggi dengan varian satu kali sehari, dua kali sehari, dan tiga kali sehari selama tiga hari. Hasil percobaan setelah ditanyakan kepada orang yang memiliki tekanan darah tinggi tersebut, hasil yang maksimal ketika dikonsumsi tiga kali sehari.

Metode ini dapat dibuat dengan diagram alir yaitu sebagai berikut:

Metode ini dapat dibuat dengan diagram alir yaitu sebagai berikut:

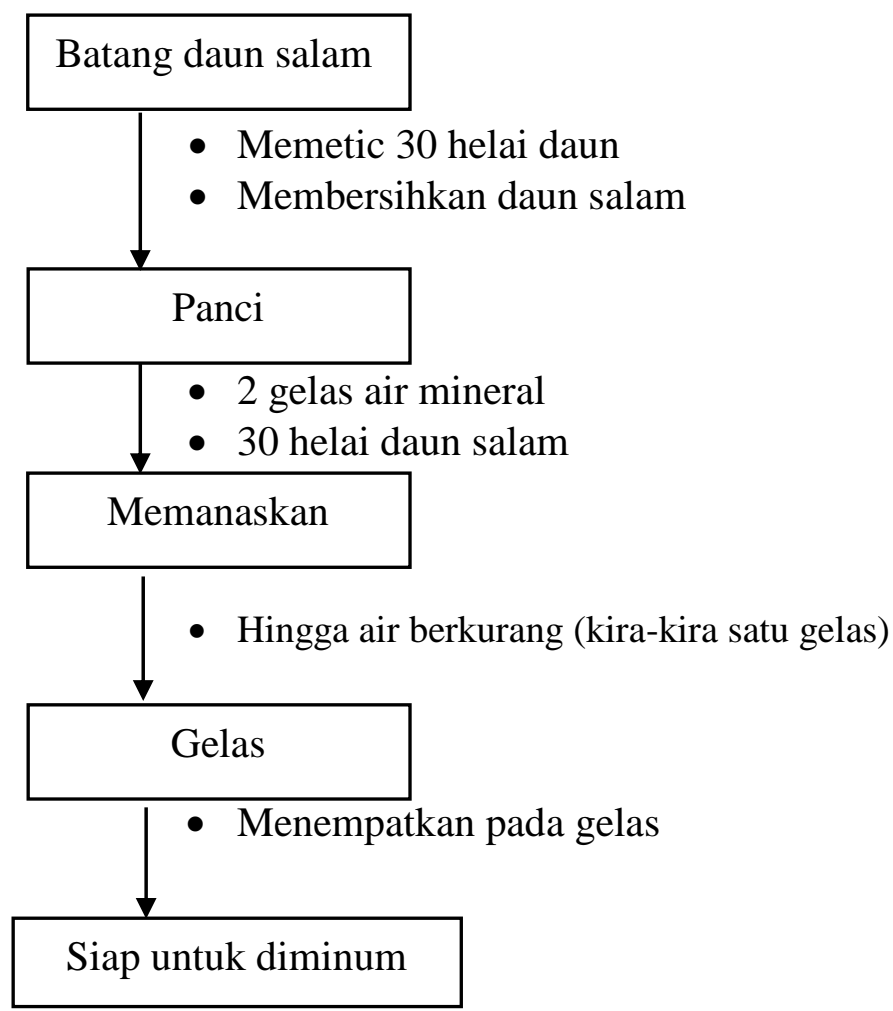

\section{Hasil dan Pembahasan}

\section{Hasil}

Hasil pembuatan rebusan diperoleh sebanyak satu gelas. Pembuatan dari 10 gram daun salam dengan dua gelas air mineral menghasilkan satu gelas ekstrak (180 $\mathrm{ml})$. Hal ini dapat dilihat dari gambar berikut: 


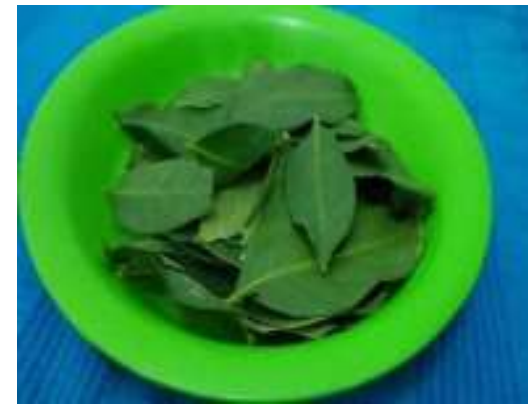

30 helai daun salam

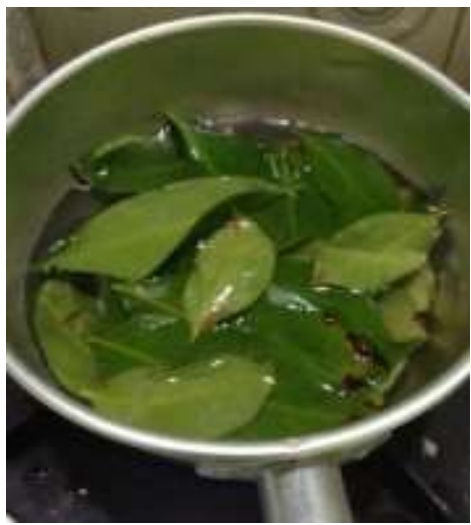

Daun salam direbus

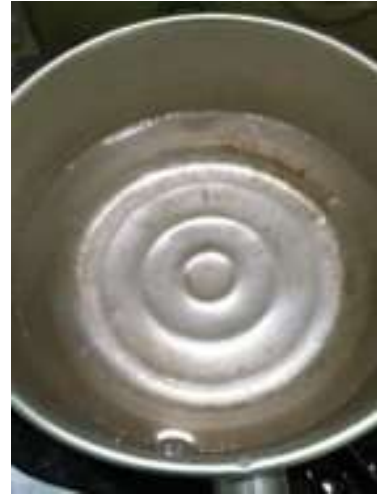

2 gelas air mineral

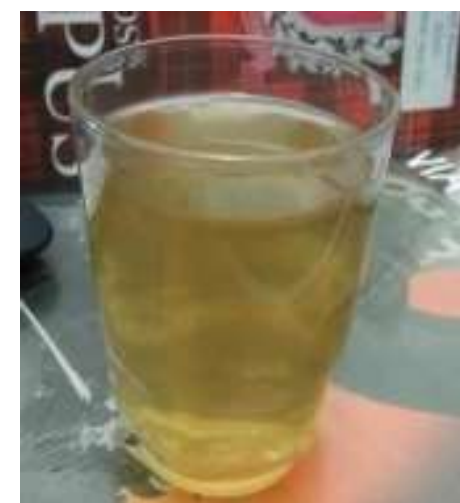

hasil rebusan daun salam

\section{Hasil Uji Coba}

Pengujian dilakukan terhadap orang yang memiliki tekanan darah tinggi ternyata berhasil menurunkan tekanan darah tinggi, dapat dilihat pada table berikut:

Tabel 1. Hasil Pengamatan pada Pemakaian Ekstrak

\begin{tabular}{ccc}
\hline Hari ke & $\begin{array}{c}\text { Jumlah } \\
\text { penggunaan } \\
(\mathbf{m l})\end{array}$ & $\begin{array}{c}\text { Tekanan } \\
\text { darah } \\
(\mathbf{m m H g})\end{array}$ \\
\hline 1 & 30 & 200 \\
2 & 40 & 190 \\
3 & 50 & 175 \\
4 & 60 & 165 \\
5 & 70 & 150 \\
6 & 80 & 148 \\
7 & 90 & 130 \\
\hline
\end{tabular}




\section{PEMBAHASAN}

1. Pembuatan

Pada saat pembuatan rebusan daun salam terdapat kendala yaitu mencari daunnya, dimana dipakai daun yang telah dewasa dengan warna hijau yang pekat. Pada saat pencarian daun banyak yang terkena hama sehingga daun salam tidak bagus dan bentuknya tidak sempurna. Daun salam harus dalam kondisi bebas hama supaya ekstrak yang dihasilkan murni dari daun salam tanpa ada pengotor dan daun yang telah dewasa agar zat-zat yang terkandung sudah cukup umur untuk direbus.

Pada saat pemanasan kendala yang dialami adalah panas yang diberikan harus konstan agar daun salam tidak cepat kering pada saat pemanasan. Api kompor yang digunakan tidak bisa diukur kekonstanan nya sehingga dikira-kira ukuran api yang diberikan pada saat pemanasan. Jadi api kompor yang digunakan sedang, tujuan nya agar pemanasan merata dan terjadi secara maksimal. Sehingga ekstrak yang dihasilkan mengandung zat yang tidak rusak. Karena panas yang berlebihan akan merusak zat-zat pada ekstrak daun salam.

Ketika memanaskan kendala yang dirasakan adalah tidak dapat nya mengukur air rebusan, karena yang dibutuhkan hanya satu gelas dari dua gelas air yang digunakan. Proses pemanasan nya harus diamati dengan seksama, bertujuan untuk memantau air rebusan, bisa jadi air rebusan keluar. Hal yang harus diperhatikan adalah pengadukan setiap 10 menit sekali, agar semua daun salam terekstrak merata pada semua bagian nya.

2. Pembahasan Uji Coba

Grafik1. Hubungan antara Penurunan Tekanan Darah dan Volume Ekstrak daun Salam

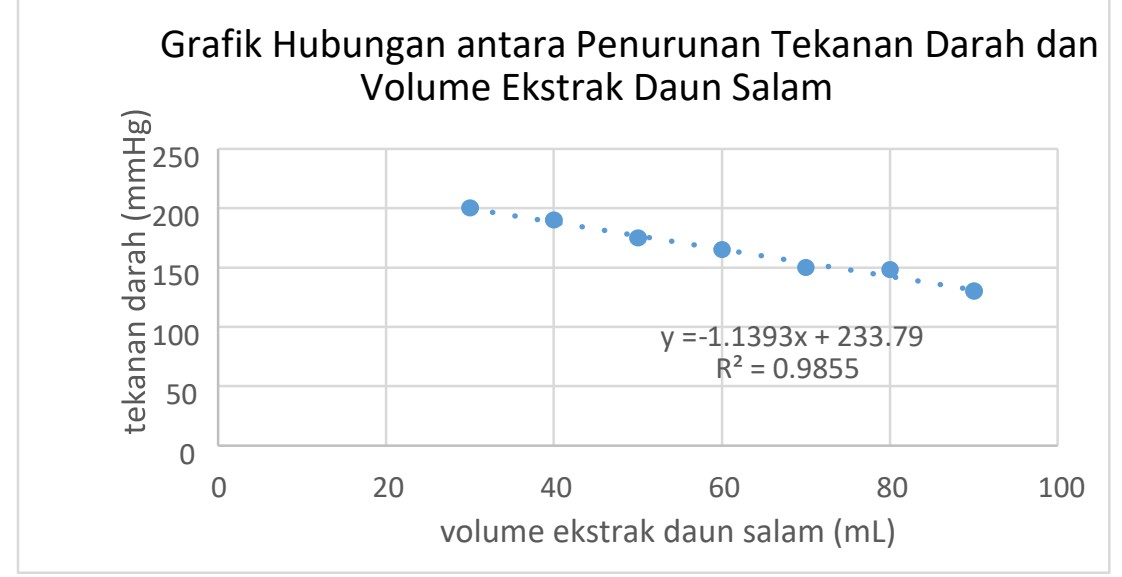

Berdasarkan dari grafik diatas dapat diketahui volume dari rebusan daun salam sangat mempengaruhi tekanan darah. Dari hasil yang dipaparkan tekanan darah turun seiring dengan bertambahnya volume air rebusan daun salam yang digunakan, karena semakin banyak air yang diminum makan akan membuat keelastisan pembuluh darah 
terjaga dan dapat menurunkan tekanan darah atau hipertensi. Penurunan grafik terjadi karena volume rebusan daun salam yang digunakan semakin banyak sehingga kandungan senyawa-senyawa yang terdapat dalam rebusan tersebut juga semakin banyak dan dapat menurunkan tekanan darah. Titik optimum dari grafik diatas pada saat volume rebusan daun salam $90 \mathrm{ml}$ dan tekanan darah $130 \mathrm{mmHg}$.

3. Intereaksi

Pada umumnya orang yang mengidap tekanan darah tinggi memiliki peningkatan arteri sehingga dapat memicu tekanan darah yang tidak normal. Hal ini dapat dipicu oleh umur, gaya hidup dan keturunan. Orang tua secara fisiologis akan mengalami peningkatan arteri, sehingga yang umumnya terkena tekanan darah tinggi adalah lansia. Untuk factor yang disebabkan oleh gaya hidup yaitu pemicu utamanya adalah makanan. Mengkonsumsi makan yang cepat saji dan mengandung kolesterol yang tinggi dapat menyebabkan tekanan darah meingkat. Factor keturunan juga menjadi pemicu utama seseorang mengidap tekanan darah tinggi. Menurut pengamatan jika orang tua mengalami takanan darah tinggi berkemungkinan besar anaknya juga akan mengidap tekanan darah tinggi atau hipertensi.

Pada usia muda jarang ditemukan penyakit hipertensi, namun laki-laki lebih berpotensi terkena hipertensi dibandingkan perempuan, karena pada perempuan terdapat hormone estrogen ${ }^{[131-132]}$ yang menekan dan melindungi dari penyakit hipertensi. Seiring berjalan nya waktu perempuan mengalami menopause yang lebih cepat dari laki-laki sehingga akan berpeluang sama mengalami hipetensi. Pada masa menopause kelenturan dari pembuluh darah akan berkurang dan berpotesi mengalami hipertensi.

Daun salam atau dengan nama latin Syzygium polyanthum banyak mengandung senyawa yang berfungsi untuk menurunkan tekanan darah tinggi, siantaranya yaitu

Saponin $^{[133]}$, flavonoid ${ }^{[134]}$, dan tannin ${ }^{[135]}$. Saponin yang terdapat dalam daun salam berfungsi sebagai antioksidan ${ }^{[136-139]}$ yang dapat mencegah terjadinya oksidasi ${ }^{[140]} \mathrm{sel}^{[141-143]}$ pada tubuh. Jika pada tubuh semakin tinggi oksidasinya maka semakin tinggi peluang untuk terkena hipertensi. Jadi kandungan flavonoid yang terdapat pada daun salam dapat mencegah penyakit hipertensi dan menurunkan kolesterol pada darah. Struktur dari flavonoid yaitu<smiles>O=c1cc(-c2ccccc2)oc2ccccc12</smiles>

https://id.wikipedia.org/wiki/Berkas:Flavon.svg 
Senyawa saponin berfungsi untuk meningkatkan kolesterol dengan adanya asam empedu sehingga dapat menurunkan kadar kolesterol dalam darah. Struktur dari saponin yaitu :

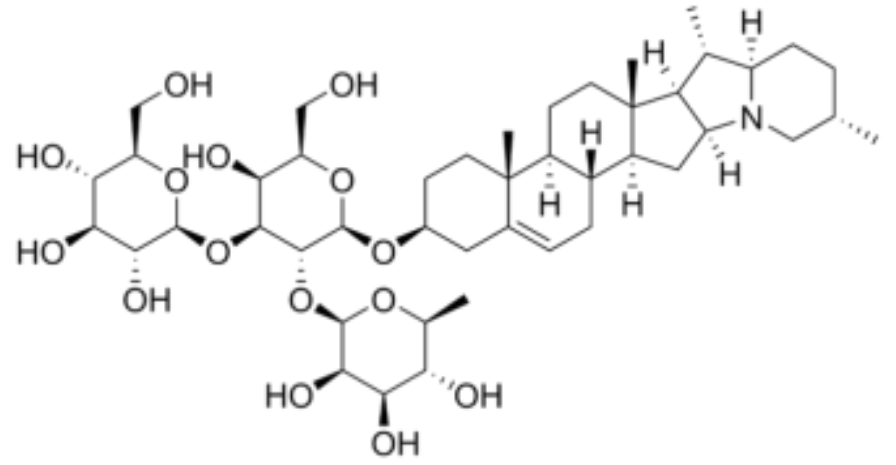

https://id.wikipedia.org/wiki/Berkas:Solanine_chemical_structure.png

Senyawa tannin berguna sebagai anti oksidan dan hipokolesterolemia ${ }^{[144-145]}$. Senyawa tannin bereaksi ${ }^{[146-147]}$ dalam tubuh dengan cara bekerja sama dengan protein mukosa dan sel epitel pada usus sehingga dapat mengurangi penyerapan lemak ${ }^{[148-149]}$. Gambar dari struktur tannin adalah<smiles></smiles>

https://id.wikipedia.org/wiki/Berkas:Tannic_acid.png

Kandungan senyawa yang dapat dalam daun salam tersebut dapat mempertahankan elastisitas pembuluh darah, sehingga dapat menurunkan kolesterol dalam darah. Terbukti dengan adanya penurunan tekanan darah dari $200 \mathrm{mmHg}$ menjadi $130 \mathrm{mmHg}$ selama tujuh hari dengan variasi ${ }^{[150]}$ volume rebusan daun salam sebagai katalis alami.

\section{KESIMPULAN}

1. Rebusan air daun salam bisa dibuat dari 10 gram daun salam dengan mencapurkan dua gelas air mineral dan dapat menghasilkan $180 \mathrm{ml}$.

2. Rebusan daun salam dapat menurunkan tekanan darah ketika diminum satu gelas tiga kali sehari. 
3. Rebusan daun salam dapat menurunkan tekanan darah tinggi atau hipertensi karena mengandung senyawa flavonoid, saponin dan tannin.

\section{REFERENSI}

[1] Ruswandi, R. (2018) "Determination of Fructose Content resulted by Inulin Hydrolysis with DNS as Oxidizer", EKSAKTA: Berkala Ilmiah Bidang MIPA, 19(1), pp. 14-23. doi: 10.24036/eksakta/vol19iss $1 / 102.2018$.

[2] Hidayani, T. (2018) "GRAFTING POLIPROPILENA DENGAN MALEAT ANHIDRIDA SEBAGAI PENGIKAT SILANG DENGAN INISIATOR BENZOIL PEROKSIDA", EKSAKTA: Berkala Ilmiah Bidang MIPA, 19(1), pp. 56-62. doi: 0.24036/eksakta/vol19-iss1/127

[3] Sanjaya, H. (2017) "DEGRADASI METHYLENE BLUE MENGGUNAKAN KATALIS ZnO-PEG DENGAN METODE FOTOSONOLISIS", EKSAKTA: Berkala Ilmiah Bidang MIPA, 18(02), pp. 21-29. doi: 10.24036/eksakta/vol18-iss02/45

[4] M., Sanjaya, H., \& Zainul, R. (2018, August 11). Characterization of napa soil and adsorption of $\mathrm{Pb}$ (II) from aqueous solutions using on column method. https://doi.org/10.31227/osf.io/t8fh9

[5] Sudding ( Uiversitas Negeri Makassar ).2013. Studi Awal Penggunaan Ekstrak Air Daun Gulma Siam Chromolaena odorata (L.) King and Robinson dalam Mencegah Pembusukan Sayuran. C H E M I C A.Vol 13, No 1.

[6] Sari, A. (2017) "POTENSI ANTIOKSIDAN ALAMI PADA EKSTRAK DAUN JAMBLANG (Syzigium cumini (L.) Skeels)", EKSAKTA: Berkala Ilmiah Bidang MIPA, 18(02), pp. 107-112. doi: 10.24036/eksakta/vol18iss02/61

[7] Yanuar, F., Tillah, M. and Devianto, D. (2018) "Modeling of Human Development Index Using Ridge Regression Method", EKSAKTA: Berkala Ilmiah Bidang MIPA, 19(2), pp. 1-11. doi: 10.24036/eksakta/vol19-iss2/134

[8] Sumarmin, R., Yuniarti, E. and Razak, A. (2017) "KUALITAS SPERMA EJAKULAT PEJANTAN AYAM KUKUAK BALENGGEK PADA PENGANDANGAN TUNGGAL TERISOLASI (Ejaculated Sperm Quality of Isolated Single Caging of Balenggek Chickens)", EKSAKTA: Berkala Ilmiah Bidang MIPA, 18(01), pp. 40-45. doi: 10.24036/eksakta/vol18-iss01/15

[9] Sanjaya, H. (2017) "DEGRADASI METHYLENE BLUE MENGGUNAKAN KATALIS ZnO-PEG DENGAN METODE FOTOSONOLISIS", EKSAKTA: Berkala Ilmiah Bidang MIPA, 18(02), pp. 21-29. doi: 10.24036/eksakta/vol18-iss02/45

[10] Ningsih, S. K. (2017) "SINTESIS DAN KARAKTERISASI NANOPARTIKEL ZnO DOPED Cu2+ MELALUI METODA SOLGEL", EKSAKTA: Berkala Ilmiah Bidang MIPA, 18(02), pp. 39-51. doi: 10.24036/eksakta/vol18-iss02/51 
[11] Hidayani, T. (2018) "GRAFTING POLIPROPILENA DENGAN MALEAT ANHIDRIDA SEBAGAI PENGIKAT SILANG DENGAN INISIATOR BENZOIL PEROKSIDA", EKSAKTA: Berkala Ilmiah Bidang MIPA, 19(1), pp. 56-62. doi: 10.24036/eksakta/vol19-iss1/127

[12] Zainul, R. (2018, August 16). Design and Modification of Copper Oxide Electrodes for Improving Conversion Coefficient Indoors Lights (PV-Cell) Photocells. https://doi.org/10.31227/osf.io/pgn84

[13] Syafei, N. (2018) "Riset Material ANALISA FENOMENA KOROSI PELAT PIPA BAJA KARBON API 5L-X65 DALAM LARUTAN 7900 ML AIR LAUT DAN 100 ML AMONIAK PADA KONDISI GAS CO2 DAN H2S JENUH PADA SUHU RUANG.", EKSAKTA: Berkala Ilmiah Bidang MIPA, 19(1), pp. 7-13. doi: 10.24036/eksakta/vol19-iss1/83

[14] Syafei, N., Hidayat, D., Emilliano, E. and Men, L. (2018) “Analysis Cracking Corrosion on Carbon Steel Pipes API 5L-X65 In Solution 7700 $\mathrm{ml}$ Aquades, $250 \mathrm{ml}$ Acetic Acid and $50 \mathrm{ml}$ Ammonia with Gas CO2 and H2S in Saturation Condition", EKSAKTA: Berkala Ilmiah Bidang MIPA, 19(2), pp. 21-31. doi: 10.24036/eksakta/vol19iss2/138

[15] Zainul, R. (2018, August 16). Determination of the half-life and the quantum yield $\mathrm{Of} \mathrm{ZnO}$ semiconductor photocatalyst in humic acid.https://doi.org/10.31227/osf.io/e8a9x

[16] chaidir, z., Zainul, R., Nurakhbari, D., \& Salim, M. (2018, July 29). Optimization of Spirulina Platensis Culture for Antioxidant Production. https://doi.org/10.17605/OSF.IO/FD6E4

[17] Kurniawati, D., Lestari, I., Harmiwati, S. S., Chaidir, Z., Munaf, E., Zein, R., ... \& Zainul, R. (2015). Biosorption of Pb (II) from aqueous solutions using column method by lengkeng (Euphoria logan lour) seed and shell. Journal of Chemical and Pharmaceutical Research, 7(12), 872-877

[18] Zainul, R., \& Dewata, I. (2015). Determination of pH-BOD-COD and degradation in batang arau watersheds at Padang city

[19] Zainul, R., Alif, A., Aziz, H., \& Arief, S. (2015). Disain Geometri Reaktor Fotosel Cahaya Ruang. Jurnal Riset Kimia, 8(2), 131

[20] Anhar, A., Sumarmin, R., \& Zainul, R. (2016). Measurement of Glycemic Index of West Sumatera Local Rice Genotypes for Healthy Food Selection. Journal of Chemical and Pharmaceutical Research, 8(8), 1035-1040

[21] Zainul, R., Alif, A., Aziz, H., Arief, S., \& Darajat, S. (2015). Modifikasi dan Karakteristik IV Sel Fotovoltaik $\mathrm{Cu} 2 \mathrm{o} / \mathrm{Cu}-\mathrm{Gel} \mathrm{Na} 2 \mathrm{so} 4$ Melalui Iluminasi Lampu Neon. Eksakta, 2, 50

[22] Yeni, Yeni Dianita ( Fakultas Kesehatan Masyarakat, Universitas Ahmad Dahlan, Yogyakarta ) , Djannah, Sitti Nur ( Fakultas Kesehatan Masyarakat, Universitas Ahmad Dahlan, Yogyakarta ), Nurani, Laela Hayu ( Fakultas Kesehatan Masyarakat, Universitas Ahmad Dahlan, Yogyakarta ).2013. UJI AKTIVITAS ANTIBAKTERI INFUSA DAUN SIRSAK (Annona muricata L.) SECARA in Vitro TERHADAP Staphylococcus aureus ATCC 25923 dan Escherichia coli ATCC 35218 SERTA PROFIL KROMATOGRAFI LAPIS TIPISNYA. Jurnal Kesehatan Masyarakat (Journal of Public Health). Vol 4, No 3

[23] Wartini Harijono, Ni Made, Susanto, Tri, Rurini Retnowati, Yunianta.2012. TINGKAT KESUKAAN DAN SENYAWA PENYUSUN 
EKSTRAK FLAVOR DAUN SALAM (EUGENIA POLYANTHA WIGHT.) DARI BEBERAOA METODE SEPARASI. Agrotekno.Vol. 14, No.2

[24] Posangi, Ira ( Bagian Farmakologi Fakultas Kedokteran Universitas Sam Ratulangi Manado ), Posangi, Jimmy ( Bagian Farmakologi Fakultas Kedokteran Universitas Sam Ratulangi Manado ), Wuisan, Jane.2013. EFEK EKSTRAK DAUN SIRSAK (ANNONA MURICATA L.) PADA KADAR KOLESTEROL TOTAL TIKUS WISTAR. JURNAL BIOMEDIK. Vol 4, No 1 (2012)

[25] IWT, Wibawan, Soejoedono, Rd, Murtini, S, Mahardika, IGK.2008. Prospek Pemanfaatan telur ayam berkhasiat anti virus avian influenza dalam usaha pengendalian infeksi virus flu burung dengan pendekatan pengebalan pasif. Jurnal Ilmu Pertanian Indonesia. Vol 13, No 3

[26] Karina, Sri Trisnowati, Didik Indradewa, Ar Roufi.2012. Pengaruh Macam dan Kadar Kitosan Terhadap Umur Simpan dan Mutu Buah Stroberi (Fragraria x ananassa Duch.). Jurnal Budidaya Pertanian.Vol 1, No 3

[27] Pudaruth, Sameerchand ( University of Mauritius ), Bhaukaurally, Bibi Feenaz, Didorally, Mohammad Haydar Ally.2012. A Semi-Automated Lyrics Generation Tool for Mauritian Sega. IAES International Journal of Artificial Intelligence (IJ-AI). Vol 1, No 4

[28] Mukaromah, Ana Hidayati, Irawan, Bagus.2012. Pemanfaatan Reaktor Membran Fotokatalitik dalam Mendegradasi Fenol dengan Katalisis TiO2 dengan Adanya Ion Logam Fe(III) dan Cu(II)

[29] Anwar, M., Munaf, E., Kosela, S., Wibowo, W., \& Zainul, R. (2015). Study of $\mathrm{Pb}$ (II) biosorption from aqueous solution using immobilized Spirogyra subsalsa biomass. Journal of Chemical and Pharmaceutical Research, 7(11), 715-722

[30] Yanto Nugroho, Duta ( Universitas Ahmad Dahlan ), Noviyanto, Fiftin ( Universitas Ahmad Dahlan ).2013. MEMBANGUN SISTEM PEMBUATAN RESEP OBAT UNTUK MENCEGAH PEMALSUAN DENGAN TEKNIK CODE GENERATOR BERBASIS WEB. Jurnal Sarjana Teknik Informatika.Vol 1, No 1

[31] Suharti, S, Banowati, A, Hermana, W, Wiryawan, K G.2010. Komposisi dan Kandungan Kolesterol Karkas Ayam Broiler Diare yang Diberi Tepung Daun Salam (Syzygium polyanthum Wight) dalam Ransum. MEDIA PETERNAKAN - Journal of Animal Science and Technology .Vol 31, No 2

[32] Sumarmin, R. (2018) "Pengaruh Ekstrak Kulit Buah Manggis (Garcinia mangostana L.) terhadap Histologis Pankreas Mencit (Mus musculus L. Swiss Webster) yang Diinduksi Sukrosa", EKSAKTA: Berkala Ilmiah Bidang MIPA, 19(1), pp. 100-112. doi: 10.24036/eksakta/vol19-iss1/123

[33] Setianto, S. (2017) "ANALISA KUANTITATIF CAMPURAN SENYAWA OKSIDA SEBAGAI DASAR IDENTIFIKASI KANDUNGAN BAHAN SUMBER DAYA ALAM Studi Kasus : Kandungan Mineral pada Pasir Besi di Pesisir Pantai Selatan, Jawa Barat", EKSAKTA: Berkala Ilmiah Bidang MIPA, 18(02), pp. 173-177. doi: 10.24036/eksakta/vol18-iss02/74 
[34] Sukarno, Inka A. T. ( Universitas Sam Ratulangi ).2014. PERBANDINGAN TEKANAN DARAH ANTARA PENDUDUK YANG TINGGAL DI DATARAN TINGGI DAN DATARAN RENDAH. Jurnal eBiomedik .Vol 2, No 1

[35] Rosyidah, Hesti ( Fakultas Kesehatan Masyarakat, Universitas Ahmad Dahlan, Yogyakarta ) , Djannah, Sitti Nur ( Fakultas Kesehatan Masyarakat, Universitas Ahmad Dahlan, Yogyakarta ).2013. HUBUNGAN ANTARA KADAR Pb DALAM DARAH DENGAN KEJADIAN HIPERTENSI PADA OPERATOR SPBU DI KOTA YOGYAKARTA. Jurnal Kesehatan Masyarakat (Journal of Public Health) .Vol 4, No 2

[36] Rizki Saputra, M. and Sumarmin, R. (2018) "PENGARUH EKSTRAK DAUN SIRIH MERAH (Piper crocatum Ruiz \& Pav.) TERHADAP GLUKOSA DARAH MENCIT (Mus musculus L.) JANTAN YANG DIINDUKSI SUKROSA", EKSAKTA: Berkala Ilmiah Bidang MIPA, 19(1), pp. 43-55. doi: 10.24036/eksakta/vol19-iss1/124

[37] Susilaningrum, D. (2017) "PEMODELAN REGRESI LOGISTIK PADA FAKTOR YANG MEMPENGARUHI PHBS PADA RUMAH TANGGA PENDERITA TBC DI PESISIR SURABAYA", EKSAKTA: Berkala Ilmiah Bidang MIPA, 18(02), pp. 121128. doi: 10.24036/eksakta/vol18iss02/65

[38] Yuliani, F., \& Zainul, R. (2018, November 13). Analisis Termodinamika Molekul Magnesium Sulphate (MgSO4). https://doi.org/10.31227/osf.io/uxz4y.2018.Analisis Termodinamika Molekul Magnesium Sulphate (MgSO4)

[39] Mawardi, M., Deyundha, D., \& Zainul, R. (2018, April). Characterization of PCC Cement by Addition of Napa Soil from Subdistrict Sarilamak 50 Kota District as Alternative Additional Material for Semen Padang. In IOP Conference Series: Materials Science and Engineering (Vol. 335, No. 1, p. 012034). IOP Publishing (40) Mardiati, Siti Muflichatun ( Biology Departement, Diponegoro University, Jl. Prof. Soedarto, SH, Tembalang Semarang ), Sitasiwi, Agung Janika ( Biology Departement, Diponegoro University, Jl. Prof. Soedarto, SH, Tembalang - Semarang). 2012. Korelasi Jumlah Folikel Ovarium dengan Konsentrasi Hormon Estrogen Mencit (Mus musculus) setelah Konsumsi Harian Tepung Kedelai selama 40 Hari. JURNAL ANATOMI FISIOLOGI .Vol 16, No 2

[40] Suharto, M. Agung Pratama, Edy, Hosea Jaya, Dumanauw2, Jovie M..2012. ISOLASI DAN IDENTIFIKASI SENYAWA SAPONIN DARI EKSTRAK METANOL BATANG PISANG AMBON(Musa paradisiaca var. sapientum L.). PHARMACON .Vol 1, No 2

[41] Parbuntari, H., Prestica, Y., Gunawan, R., Nurman, M. and Adella, F. (2018) "Preliminary Phytochemical Screening (Qualitative Analysis) of Cacao Leaves (Theobroma cacao L.)", EKSAKTA: Berkala Ilmiah Bidang MIPA, 19(2), pp. 40-45. doi: 10.24036/eksakta/vol19-iss2/142

[42] Santoso, B, Hariadia, B Tj, Manik, H, Abubakar, H.2011. Silage Quality of King Grass (Pennisetum purpureophoides) Treated with Epiphytic Lactic Acid Bacteria and Tannin of Acacia. MEDIA PETERNAKAN Journal of Animal Science and Technology. Vol 34, No 2 (2011) 
[43] Sari, A. (2017) "POTENSI ANTIOKSIDAN ALAMI PADA EKSTRAK DAUN JAMBLANG (Syzigium cumini (L.) Skeels)", EKSAKTA: Berkala Ilmiah Bidang MIPA, 18(02), pp. 107-112. doi: 10.24036/eksakta/vol18iss02/61

[44] Nurlaili, Enny Purwati, Astuti, Mary, Marsono, Y.2012. EFEK SUPLEMENTASI LAKTOFERIN PADA SUSU FORMULA TERHADAP AVAILABILITAS ZAT BESI, OKSIDASI LEMAK DAN PERTUMBUHAN Escherichia coli PADA SALURAN

a. PENCERNAAN TIKUS [The Effects of Lactoferrin Supplementation to Infant Formula on Iron Availability, Lipid O. Jurnal Teknologi Dan Industri Pangan.Vol 13 , No 3

[45] Kurniawan, Wayan Damar Windu ( Fakultas Geografi UGM ), Farda, Nur Mohammad ( Fakultas Geografi UGM ).2013. Fuzzy Neural Network Capability Studies in Land Cover Perpiksel Based Classification Using Landsat7 ETM+. Jurnal Bumi Indonesia.Volume 2, Nomor 1

[46] Alfionita, T., \& Zainul, R. (2019, January 29). Calcium Chloride (CaCl2) : Characteristics and Molecular Interaction in Solution.2018

[47] Husna, A. D., \& Zainul, R. (2019, February 4). Analisis Molekular dan Karakteristik Hidrogen Sianida (HCN). 2018

[48] JURNAL KESEHATAN MASYARAKAT INDONESIA.2012. HUBUNGAN KONSUMSI LEMAK DENGAN KEJADIAN HIPERKOLESTEROLEMIA PADA PASIEN RAWAT JALAN DI POLIKLINIK JANTUNG RUMAH SAKIT UMUM DAERAH KRATON KABUPATEN PEKALONGAN. JURNAL KESEHATAN

[49] MASYARAKAT INDONESIA. Vol 6, No 1 (2010)

[50] Sanjaya, H. (2018) "DEGRADASI METIL VIOLET MENGGUNAKAN KATALIS ZnO-TiO2 SECARA FOTOSONOLISIS", EKSAKTA: Berkala Ilmiah Bidang MIPA, 19(1), pp. 91-99. doi: 10.24036/eksakta/vol19-iss1/131

[51] Yanti, C. F., \& Zainul, R. (2018, December 2). A Review Ba (OH)2 : Transpor Ionik pada Barium Hidroksida di dalam Air dengan Konsep Termodinamika. https://doi.org/10.31227/osf.io/fsbq3

[52] Dinata, A. A., Rosyadi, A. M., Hamid, S., \& Zainul, R. (2018, October 15). A Review CHEMICAL VAPOR DEPOSITION : PROCESS AND APPLICATION. https://doi.org/10.31227/osf.io/yfeau

[53] P, O. M., A, L. G., S, A. Y. M., \& Zainul, R. (2018, October 12). A Review Grinding : Teknik dan Prinsip Dasar pada Pengolahan Material. https://doi.org/10.31227/osf.io/trv4q

[54] Febriani, S. S., Yolanda, T., Arianti, V. A., \& Zainul, R. (2018, October 12). A Review Solid Stated : Principles and Methode. https://doi.org/10.31227/osf.io/7us4x

[55] Putri, D. F., Ritonga, H. M., Murdiati, V., \& Zainul, R. (2018, October 15). A REVIEW WHAT IS HYDROTHERMAL ?. https://doi.org/10.31227/osf.io/dm56c

[56] Husna, H., \& Zainul, R. (2019, February 3). A Review : Aspek Termodinamika LiNO3 dalam Larutannya. https://doi.org/10.31227/osf.io/45mbd 
[57] Husna, A. D., \& Zainul, R. (2019, February 4). Analisis Molekular dan Karakteristik Hidrogen Sianida (HCN). https://doi.org/10.31227/osf.io/7xej9

[58] Kristy, D. P., \& Zainul, R. (2019, February 3). Analisis Molekular dan Transpor Ion Natrium Silikat. https://doi.org/10.31227/osf.io/8ac4m

[59] Yuliani, F., \& Zainul, R. (2018, November 13). Analisis Termodinamika Molekul Magnesium Sulphate (MgSO4). https://doi.org/10.31227/osf.io/uxz4y

[60] Hakimi, A., \& Zainul, R. (2019, January 31). Asam Arsenat (H3AsO4) : Analisis Molekular dan Karakteristik Senyawa. https://doi.org/10.31227/osf.io/e486z

[61] Warlinda, Y. A., \& Zainul, R. (2019, January 29). Asam Posfat (H3PO4): Ionic Transformation of Phosphoric Acid in Aqueous Solution. https://doi.org/10.31227/osf.io/s3y8v

[62] Dwynda, I., \& Zainul, R. (2018, November 19). Boric Acid (H3 (BO3): Recognize The Molecular Interactions in Solutions. https://doi.org/10.31227/osf.io/6wead

[63] Alfionita, T., \& Zainul, R. (2019, January 29). Calcium Chloride (CaCl2) : Characteristics and Molecular Interaction in Solution. https://doi.org/10.31227/osf.io/m37xj

[64] M., Sanjaya, H., \& Zainul, R. (2018, August 11). Characterization of napa soil and adsorption of $\mathrm{Pb}$ (II) from aqueous solutions using on column method. https://doi.org/10.31227/osf.io/t8fh9

[65] Yulis, R., Zainul, R., \& M. (2018, December 10). DESAIN DAN KARAKTERISASI SEL SURYA SISTEM ELEKTRODA TEMBAGA (I) OKSIDA (Cu2O/Al) MODEL PIPA PADA LARUTAN NATRIUM SULFAT (Na2SO4). https://doi.org/10.31227/osf.io/m43js

[66] Zainul, R., \& Prima, C. B. (2018, November 11). Desain Geometri Sel PV. https://doi.org/10.31227/osf.io/7n8t4

[67] Zainul, R. (2018, August 16). Design and Modification of Copper Oxide Electrodes for Improving Conversion Coefficient Indoors Lights (PV-Cell) Photocells. https://doi.org/10.31227/osf.io/pgn84

[68] Zainul, R. (2018, August 16). Determination of the half-life and the quantum yield of $\mathrm{ZnO}$ semiconductor photocatalyst in humic acid. https://doi.org/10.31227/osf.io/e8a9x

[69] Feronika, N. I., \& Zainul, R. (2018, November 19). Kalium Permanganat: Termodinamika Mengenai Transport Ionik dalam Air. https://doi.org/10.31227/osf.io/g6eyk

[70] Delvi, I. P., \& Zainul, R. (2019, February 3). Mercury (II) Nitrate (Hg (NO3)2): Interaksi Molekul dan Adsorpsi $\mathrm{Hg}$ dengan Karbon Aktif. https://doi.org/10.31227/osf.io/eqyax

[71] Putri, G. E., Arief, S., Jamarun, N., Gusti, F. R., \& Zainul, R. (2018, December 10). Microstuctural Analysis and Optical Properties of Nanocrystalline Cerium Oxides Synthesized by Precipitation Method. https://doi.org/10.31227/osf.io/qcz4y

[72] Jumalia, R., \& Zainul, R. (2019, February 3). Natrium Karbonat : Termodinamika dan Transport Ion. https://doi.org/10.31227/osf.io/y2vq9 
[73] Sari, E. S. J., \& Zainul, R. (2019, January 31). Nitrogen Triflorida (NF3) : Termodinamika dan Transpor Elektron NF3. https://doi.org/10.31227/osf.io/3nzrh

[74] chaidir, z., Zainul, R., Nurakhbari, D., \& Salim, M. (2018, July 29). Optimization of Spirulina Platensis Culture for Antioxidant Production. https://doi.org/10.17605/OSF.IO/FD6E4

[75] Zainul, R., Alif, A., Aziz, H., Arief, S., \& s. (2018, August 16). Photoelectrosplitting Water Mechanism at Carbon Electrode Surface using Indoor lights. https://doi.org/10.31227/osf.io/vcxq8

[76] Artika, P. I., \& Zainul, R. (2018, November 19). Potassium Bromide (KBr): Transformasi ionik dan sifat temodinamika dalam Larutan. https://doi.org/10.31227/osf.io/a5hyz

[77] Zainul, R., \& Prima, C. B. (2018, December 9). TEKNOLOGI MATERIAL MAJU Prinsip Dasar dan Aspek Rekayasa. https://doi.org/10.31227/osf.io/p63wc

[78] H., Azhar, M., \& Zainul, R. (2018, September 19). THE EFFECTIVENESS OF STRUCTURED INQUIRY BASED MODULE TO IMPROVE MENTAL MODEL OF CONCEPT MOLE. https://doi.org/10.31227/osf.io/ckjtb

[79] Shafitri, M., \& Zainul, R. (2019, February 3). Vanadium Pentaoksida (V2O5) : Termodinamika Molecular dan Interaksi Ion dalam Larutan. https://doi.org/10.31227/osf.io/jgmvd

[80] Sanjaya, H. (2018) "DEGRADASI METIL VIOLET MENGGUNAKAN KATALIS ZnO-TiO2 SECARA FOTOSONOLISIS”, EKSAKTA: Berkala Ilmiah Bidang MIPA, 19(1), pp. 91-99. doi: 10.24036/eksakta/vol19iss $1 / 131$.

[81] Ningsih, S. K. (2017) "SINTESIS DAN KARAKTERISASI NANOPARTIKEL ZnO DOPED Cu2+ MELALUI METODA SOLGEL", EKSAKTA: Berkala Ilmiah Bidang MIPA, 18(02), pp. 39-51. doi: 10.24036/eksakta/vol18-iss02/51.

[82] Saiya, A. (2017) "ANALISIS RESIDU KLORPIRIFOS DALAM SAYURAN KUBIS DENGAN METODE HPLC DI BEBERAPA PASAR TRADISIONAL DI SULAWESI UTARA", EKSAKTA: Berkala Ilmiah Bidang MIPA, 18(02), pp. 77-85. doi: 10.24036/eksakta/vol18-iss02/57.

[83] Mulia, M. (2017) "ISOLASI KUMARIN DARI KULIT BUAH LIMAU SUNDAI (Citrus nobilis Lour)", EKSAKTA: Berkala Ilmiah Bidang MIPA, 18(02), pp. 137-145. doi: 10.24036/eksakta/vol18-iss02/70.

[84] Azhar, M., Ahda, Y., Ihsanawati, I., Puspasari, F., Mawarni, S., Risa, B. and Natalia, D. (2017) "SKRINING BAKTERI PENDEGRADASI INULIN DARI RIZOSFER UMBI DAHLIA MENGGUNAKAN INULIN UMBI DAHLIA", EKSAKTA: Berkala Ilmiah Bidang MIPA, 18(02), pp. 13-20. doi: 10.24036/eksakta/vol18-iss02/44.

[85] Tutuarima, T. (2017) "SIFAT FISIK DAN KIMIA MARMALADE JERUK KALAMANSI (Citrus microcarpa) : KAJIAN KONSENTRASI PEKTIN DAN SUKROSA Physical and Chemical Properties of Marmalade Citrus of Calamondin (Citrus microcarpa) : Study of Pectin and Sucrose Concentrations", EKSAKTA: Berkala Ilmiah Bidang MIPA, 18(02), pp. 164-172. doi: 10.24036/eksakta/vol18-iss02/73. 
[86] Sanjaya, H. (2017) "DEGRADASI METHYLENE BLUE MENGGUNAKAN KATALIS ZnO-PEG DENGAN METODE FOTOSONOLISIS", EKSAKTA: Berkala Ilmiah Bidang MIPA, 18(02), pp. 21-29. doi: 10.24036/eksakta/vol18-iss02/45.

[87] Suryelita, S., Etika, S. B. and Kurnia, N. S. (2017) "ISOLASI DAN KARAKTERISASI SENYAWA STEROID DARI DAUN CEMARA NATAL (Cupressus funebris Endl.)", EKSAKTA: Berkala Ilmiah Bidang MIPA, 18(01), pp. 86-94. doi: 10.24036/eksakta/vol18-iss01/23.

[88] Iryani, I., Iswendi, I. and Katrina, I. T. (2017) "UJI AKTIVITAS ANTI DIABETES MELLITUS SENYAWA METABOLIT SEKUNDER FRAKSI AIR DARI BERAS KETAN HITAM ( Oryza satival. Var glutinosa) PADA MENCIT PUTIH", EKSAKTA: Berkala Ilmiah Bidang MIPA, 18(01), pp. 54-60. doi: 10.24036/eksakta/vol18-iss01/17.

[89] Hidayat, D. (2018) “ANALISIS RESPON PENGONTROL ON-OFF PADA KENDALI UMPAN BALIK SISTEM FISIS ELEKTRONIK", EKSAKTA: Berkala Ilmiah Bidang MIPA, 19(1), pp. 118124. doi: 10.24036/eksakta/vol19-iss1/119.

[90] Ningsih, S. K. (2017) "SINTESIS DAN KARAKTERISASI NANOPARTIKEL ZnO DOPED Cu2+ MELALUI METODA SOLGEL", EKSAKTA: Berkala Ilmiah Bidang MIPA, 18(02), pp. 39-51. doi: 10.24036/eksakta/vol18-iss02/51.

[91] Amananti, W. (2017) "ANALISIS MIKROSTRUKTUR LAPISAN TIPIS TiO2:ZnO YANG DIDEPOSISIKAN DIATAS SUBTRAT KACA DENGAN METODE SPRAY COATING UNTUK DEGRADASI LIMBAH ZAT WARNA", EKSAKTA: Berkala Ilmiah Bidang MIPA, 18(02), pp. 210-215. doi: 10.24036/eksakta/vol18-iss02/81.

[92] Setianto S. ANALISA KUANTITATIF CAMPURAN SENYAWA OKSIDA SEBAGAI DASAR IDENTIFIKASI KANDUNGAN BAHAN SUMBER DAYA ALAM Studi Kasus : Kandungan Mineral pada Pasir Besi di Pesisir Pantai Selatan, Jawa Barat. EKSAKTA [Internet]. 30Nov.2017 [cited 11May2019];18(02):173-7. Available from: http://eksakta.ppj.unp.ac.id/index.php/eksakta/article/view/74

[93] Syafei, N. (2017) “ANALISA FENOMENA KOROSI PELAT PIPA BAJA KARBON API 5L-X65 DALAM LARUTAN 250 ML ASAM ASETAT DAN 4750 ML AQUADES PADA KONDISI GAS CO2 DAN H2S JENUH PADA SUHU RUANG", EKSAKTA: Berkala Ilmiah Bidang MIPA, 18(02), pp. 113-120. doi: 10.24036/eksakta/vol18-iss02/63.

[94] Tutuarima, T. (2017) "SIFAT FISIK DAN KIMIA MARMALADE JERUK KALAMANSI (Citrus microcarpa) : KAJIAN KONSENTRASI PEKTIN DAN SUKROSA Physical and Chemical Properties of Marmalade Citrus of Calamondin (Citrus microcarpa) : Study of Pectin and Sucrose Concentrations", EKSAKTA: Berkala Ilmiah Bidang MIPA, 18(02), pp. 164-172. doi: 10.24036/eksakta/vol18-iss02/73.

[95] Ningsih SK. SINTESIS DAN KARAKTERISASI NANOPARTIKEL ZnO DOPED Cu2+ MELALUI METODA SOL-GEL. EKSAKTA [Internet]. 30Nov.2017 [cited 11May2019];18(02):39-1. Available from: http://eksakta.ppj.unp.ac.id/index.php/eksakta/article/view/51 
[96] Ruswandi R. Determination of Fructose Content resulted by Inulin Hydrolysis with DNS as Oxidizer. EKSAKTA [Internet]. 21Apr.2018 [cited 11May2019];19(1):14-3. Available from: http://eksakta.ppj.unp.ac.id/index.php/eksakta/article/view/102

[97] Iskandar, I., Horiza, H. and Fauzi, N. (2017) "EFEKTIVITAS BUBUK BIJI PEPAYA (Carica Papaya Linnaeaus) SEBAGAI LARVASIDA ALAMI TERHADAP KEMATIAN LARVA AEDES AEGYPTY TAHUN 2015", EKSAKTA: Berkala Ilmiah Bidang MIPA, 18(01), pp. 12-18. doi: 10.24036/eksakta/vol18-iss01/12.

[98] Zainul, R. and Wardani, S. (2019) "The Hydrogen Generator Performance of Sandwich Designed 4/4 Al-Cu Plates", EKSAKTA: Berkala Ilmiah Bidang MIPA, 20(1), pp. 100-104. doi: 10.24036/eksakta/vol20-iss1/177.

[99] Syafei, N. (2018) "Riset Material ANALISA FENOMENA KOROSI PELAT PIPA BAJA KARBON API 5L-X65 DALAM LARUTAN 7900 ML AIR LAUT DAN 100 ML AMONIAK PADA KONDISI GAS CO2 DAN H2S JENUH PADA SUHU RUANG.", EKSAKTA: Berkala Ilmiah Bidang MIPA, 19(1), pp. 7-13. doi: 10.24036/eksakta/vol19-iss1/83.

[100] Syafei, N. (2017) “ANALISA FENOMENA KOROSI PELAT PIPA BAJA KARBON API 5L-X65 DALAM LARUTAN 250 ML ASAM ASETAT DAN 4750 ML AQUADES PADA KONDISI GAS CO2 DAN H2S JENUH PADA SUHU RUANG", EKSAKTA: Berkala Ilmiah Bidang MIPA, 18(02), pp. 113-120. doi: 10.24036/eksakta/vol18-iss02/63.

[101] Ruswandi, R. (2018) "Determination of Fructose Content resulted by Inulin Hydrolysis with DNS as Oxidizer", EKSAKTA: Berkala Ilmiah Bidang MIPA, 19(1), pp. 14-23. doi: 10.24036/eksakta/vol19-iss1/102.

[102] Saiya, A. (2017) "ANALISIS RESIDU KLORPIRIFOS DALAM SAYURAN KUBIS DENGAN METODE HPLC DI BEBERAPA PASAR TRADISIONAL DI SULAWESI UTARA", EKSAKTA: Berkala Ilmiah Bidang MIPA, 18(02), pp. 77-85. doi: 10.24036/eksakta/vol18-iss02/57.

[103] Dinata, M. and Soehardi, F. (2018) "Factor Analysis of Physics Chemistry Waters that Affects Damage Safety Cliff on the Outskirts of River Siak", EKSAKTA: Berkala Ilmiah Bidang MIPA, 19(2), pp. 46-49. doi: 10.24036/eksakta/vol19-iss2/143.

[104] Putri, D., Fifendy, M. and putri, M. (2018) "DIVERSITAS BAKTERI ENDOFIT PADA DAUN MUDA DAN TUA TUMBUHAN ANDALEH (Morus macroura miq.)", EKSAKTA: Berkala Ilmiah Bidang MIPA, 19(1), pp. 125-130. doi: 10.24036/eksakta/vol19-iss1/122.

[105] Sumarmin, R. (2018) "Pengaruh Ekstrak Kulit Buah Manggis (Garcinia mangostana L.) terhadap Histologis Pankreas Mencit (Mus musculus L. Swiss Webster) yang Diinduksi Sukrosa", EKSAKTA: Berkala Ilmiah Bidang MIPA, 19(1), pp. 100-112. doi: 10.24036/eksakta/vol19-iss1/123.

[106] Syafei, N. (2018) "Riset Material ANALISA FENOMENA KOROSI PELAT PIPA BAJA KARBON API 5L-X65 DALAM LARUTAN 7900 ML AIR LAUT DAN 100 ML AMONIAK PADA KONDISI GAS CO2 DAN H2S JENUH PADA SUHU RUANG.", EKSAKTA: Berkala Ilmiah Bidang MIPA, 19(1), pp. 7-13. doi: 10.24036/eksakta/vol19-iss1/83.

[107] Setianto, S. (2017) "ANALISA KUANTITATIF CAMPURAN SENYAWA OKSIDA SEBAGAI DASAR IDENTIFIKASI 
KANDUNGAN BAHAN SUMBER DAYA ALAM Studi Kasus : Kandungan Mineral pada Pasir Besi di Pesisir Pantai Selatan, Jawa Barat", EKSAKTA: Berkala Ilmiah Bidang MIPA, 18(02), pp. 173-177. doi: 10.24036/eksakta/vol18-iss02/74.

[108] Setianto, S. (2017) "ANALISA KUANTITATIF CAMPURAN SENYAWA OKSIDA SEBAGAI DASAR IDENTIFIKASI KANDUNGAN BAHAN SUMBER DAYA ALAM Studi Kasus : Kandungan Mineral pada Pasir Besi di Pesisir Pantai Selatan, Jawa Barat", EKSAKTA: Berkala Ilmiah Bidang MIPA, 18(02), pp. 173-177. doi: 10.24036/eksakta/vol18-iss02/74.

[109] Rizki Saputra, M. and Sumarmin, R. (2018) "PENGARUH EKSTRAK DAUN SIRIH MERAH (Piper crocatum Ruiz \& Pav.) TERHADAP GLUKOSA DARAH MENCIT (Mus musculus L.) JANTAN YANG DIINDUKSI SUKROSA", EKSAKTA: Berkala Ilmiah Bidang MIPA, 19(1), pp. 43-55. doi: 10.24036/eksakta/vol19-iss1/124.

[110] Dinata, M. and Soehardi, F. (2018) "Factor Analysis of Physics Chemistry Waters that Affects Damage Safety Cliff on the Outskirts of River Siak", EKSAKTA: Berkala Ilmiah Bidang MIPA, 19(2), pp. 46-49. doi: 10.24036/eksakta/vol19-iss2/143.

[111] Syafei, N. (2018) "Riset Material ANALISA FENOMENA KOROSI PELAT PIPA BAJA KARBON API 5L-X65 DALAM LARUTAN 7900 ML AIR LAUT DAN 100 ML AMONIAK PADA KONDISI GAS CO2 DAN H2S JENUH PADA SUHU RUANG.”, EKSAKTA: Berkala Ilmiah Bidang MIPA, 19(1), pp. 7-13. doi: 10.24036/eksakta/vol19-iss1/83.

[112] Horiza, H. (2018) "The influence of the use of activated carbon Fibres of the cane Against the drop in Salinity In the well Dig In RT 003 RW 006 Village Cape Town Unggat Tanjungpinang Year 2017', EKSAKTA: Berkala Ilmiah Bidang MIPA, 19(1), pp. 1-6. doi: 10.24036/eksakta/vol19iss $1 / 97$.

[113] Ruswandi, R. (2018) "Determination of Fructose Content resulted by Inulin Hydrolysis with DNS as Oxidizer", EKSAKTA: Berkala Ilmiah Bidang MIPA, 19(1), pp. 14-23. doi: 10.24036/eksakta/vol19-iss1/102.

[114] Sudrajat, R. (2017) “TINJAUAN TENTANG KETERKAITAN PARAMETER DENGAN MODEL REGRESI MULTIVARIAT PADA KOLAM IKAN TERTUTUP”, EKSAKTA: Berkala Ilmiah Bidang MIPA, 18(02), pp. 158-163. doi: 10.24036/eksakta/vol18-iss02/72.

[115] Susilaningrum, D. (2017) "PEMODELAN REGRESI LOGISTIK PADA FAKTOR YANG MEMPENGARUHI PHBS PADA RUMAH TANGGA PENDERITA TBC DI PESISIR SURABAYA", EKSAKTA: Berkala Ilmiah Bidang MIPA, 18(02), pp. 121-128. doi: 10.24036/eksakta/vol18-iss02/65.

[116] Prihatini, R. (2017) "PEMANFAATAN AIR KELAPA UNTUK MENINGKATKAN PERTUMBUHAN AKAR STEK TUNAS AKSILAR Andrographis paniculata Nees", EKSAKTA: Berkala Ilmiah Bidang MIPA, 18(02), pp. 62-68. doi: 10.24036/eksakta/vol18-iss02/54.

[117] Amir, H., Akmam, A., Bavitra, B. and Azhari, M. (2017) "PENENTUAN KEDALAMAN BATUAN DASAR MENGGUNAKAN METODE GEOLISTRIK TAHANAN JENIS DENGAN MEMBANDINGKAN KONFIGURASI DIPOLE-DIPOLE DAN WENNER DI BUKIT APIT 
PUHUN KECAMATAN GUGUK PANJANG KOTA BUKITTINGGI", EKSAKTA: Berkala Ilmiah Bidang MIPA, 18(01), pp. 1930. doi: 10.24036/eksakta/vol18-iss01/13.

[118] Rizki Saputra, M. and Sumarmin, R. (2018) "PENGARUH EKSTRAK DAUN SIRIH MERAH (Piper crocatum Ruiz \& Pav.) TERHADAP GLUKOSA DARAH MENCIT (Mus musculus L.) JANTAN YANG DIINDUKSI SUKROSA", EKSAKTA: Berkala Ilmiah Bidang MIPA, 19(1), pp. 43-55. doi: 10.24036/eksakta/vol19-iss1/124.

[119] Putri, D., Fifendy, M. and putri, M. (2018) "DIVERSITAS BAKTERI ENDOFIT PADA DAUN MUDA DAN TUA TUMBUHAN ANDALEH (Morus macroura miq.)", EKSAKTA: Berkala Ilmiah Bidang MIPA, 19(1), pp. 125-130. doi: 10.24036/eksakta/vol19-iss1/122.

[120] Dinata, M., Fitridawati, F. and Putri, L. (2019) "The Study Trees Potential for Forest in Universitas Lancang Kuning Pekanbaru”, EKSAKTA: Berkala Ilmiah Bidang MIPA, 20(1), pp. 77-85. doi: 10.24036/eksakta/vol20iss1/176.

[121] Ruswandi, R. (2018) "Determination of Fructose Content resulted by Inulin Hydrolysis with DNS as Oxidizer", EKSAKTA: Berkala Ilmiah Bidang MIPA, 19(1), pp. 14-23. doi: 10.24036/eksakta/vol19-iss1/102.

[122] Amananti, W. (2017) “ANALISIS MIKROSTRUKTUR LAPISAN TIPIS TiO2:ZnO YANG DIDEPOSISIKAN DIATAS SUBTRAT KACA DENGAN METODE SPRAY COATING UNTUK DEGRADASI LIMBAH ZAT WARNA", EKSAKTA: Berkala Ilmiah Bidang MIPA, 18(02), pp. 210-215. doi: 10.24036/eksakta/vol18-iss02/81.

[123] Rizki Saputra, M. and Sumarmin, R. (2018) "PENGARUH EKSTRAK DAUN SIRIH MERAH (Piper crocatum Ruiz \& Pav.) TERHADAP GLUKOSA DARAH MENCIT (Mus musculus L.) JANTAN YANG DIINDUKSI SUKROSA", EKSAKTA: Berkala Ilmiah Bidang MIPA, 19(1), pp. 43-55. doi: 10.24036/eksakta/vol19-iss1/124.

[124] Yanuar, F., Tillah, M. and Devianto, D. (2018) "Modeling of Human Development Index Using Ridge Regression Method", EKSAKTA: Berkala Ilmiah Bidang MIPA, 19(2), pp. 1-11. doi: 10.24036/eksakta/vol19iss $2 / 134$.

[125] Dinata, M. and Soehardi, F. (2018) "Factor Analysis of Physics Chemistry Waters that Affects Damage Safety Cliff on the Outskirts of River Siak", EKSAKTA: Berkala Ilmiah Bidang MIPA, 19(2), pp. 46-49. doi: 10.24036/eksakta/vol19-iss2/143.

[126] Yanuar, F., Tillah, M. and Devianto, D. (2018) "Modeling of Human Development Index Using Ridge Regression Method", EKSAKTA: Berkala Ilmiah Bidang MIPA, 19(2), pp. 1-11. doi: 10.24036/eksakta/vol19iss $2 / 134$.

[127] Sanjaya, H. (2017) "DEGRADASI METHYLENE BLUE MENGGUNAKAN KATALIS ZnO-PEG DENGAN METODE FOTOSONOLISIS", EKSAKTA: Berkala Ilmiah Bidang MIPA, 18(02), pp. 21-29. doi: 10.24036/eksakta/vol18-iss02/45.

[128] Hidayani, T. (2018) "GRAFTING POLIPROPILENA DENGAN MALEAT ANHIDRIDA SEBAGAI PENGIKAT SILANG DENGAN 
INISIATOR BENZOIL PEROKSIDA”, EKSAKTA: Berkala Ilmiah Bidang MIPA, 19(1), pp. 56-62. doi: 10.24036/eksakta/vol19-iss1/127.

[129] Samah, S. (2017) "KARAKTERISASI PLASTIK BIODEGRADABEL DARI LDPE-g-MA DAN PATI TANDAN KOSONG SAWIT”, EKSAKTA: Berkala Ilmiah Bidang MIPA, 18(02), pp. 30-38. doi: 10.24036/eksakta/vol18-iss02/48.

[130] Santoso, B. (2018) "IDENTIFIKASI AKUIFER MENGGUNAKAN METODE GEOLISTRIK RESISTIVITAS DI DAERAH BEBANDEM, KARANG ASEM, BALI", EKSAKTA: Berkala Ilmiah Bidang MIPA, 19(1), pp. 24-34. doi: 10.24036/eksakta/vol19-iss 1/101.

[131] Amananti, W. (2017) "ANALISIS MIKROSTRUKTUR LAPISAN TIPIS TiO2:ZnO YANG DIDEPOSISIKAN DIATAS SUBTRAT KACA DENGAN METODE SPRAY COATING UNTUK DEGRADASI LIMBAH ZAT WARNA", EKSAKTA: Berkala Ilmiah Bidang MIPA, 18(02), pp. 210-215. doi: 10.24036/eksakta/vol18-iss02/81.

[132] Putri, D., Fifendy, M. and putri, M. (2018) "DIVERSITAS BAKTERI ENDOFIT PADA DAUN MUDA DAN TUA TUMBUHAN ANDALEH (Morus macroura miq.)", EKSAKTA: Berkala Ilmiah Bidang MIPA, 19(1), pp. 125-130. doi: 10.24036/eksakta/vol19-iss1/122.

[133] Yanuar, F., Tillah, M. and Devianto, D. (2018) "Modeling of Human Development Index Using Ridge Regression Method", EKSAKTA: Berkala Ilmiah Bidang MIPA, 19(2), pp. 1-11. doi: 10.24036/eksakta/vol19iss $2 / 134$.

[134] Hidayani, T. (2018) “GRAFTING POLIPROPILENA DENGAN MALEAT ANHIDRIDA SEBAGAI PENGIKAT SILANG DENGAN INISIATOR BENZOIL PEROKSIDA”, EKSAKTA: Berkala Ilmiah Bidang MIPA, 19(1), pp. 56-62. doi: 10.24036/eksakta/vol19-iss1/127.

[135] Susilaningrum, D. (2017) "PEMODELAN REGRESI LOGISTIK PADA FAKTOR YANG MEMPENGARUHI PHBS PADA RUMAH TANGGA PENDERITA TBC DI PESISIR SURABAYA", EKSAKTA: Berkala Ilmiah Bidang MIPA, 18(02), pp. 121-128. doi: 10.24036/eksakta/vol18-iss02/65.

[136] Ruswandi, R. (2018) "Determination of Fructose Content resulted by Inulin Hydrolysis with DNS as Oxidizer", EKSAKTA: Berkala Ilmiah Bidang MIPA, 19(1), pp. 14-23. doi: 10.24036/eksakta/vol19-iss1/102.

[137] Horiza, H. (2018) "The influence of the use of activated carbon Fibres of the cane Against the drop in Salinity In the well Dig In RT 003 RW 006 Village Cape Town Unggat Tanjungpinang Year 2017", EKSAKTA: Berkala Ilmiah Bidang MIPA, 19(1), pp. 1-6. doi: 10.24036/eksakta/vol19iss $1 / 97$.

[138] Badrulfalah, B. (2018) "SUB RUANG TUTUP TOPOLOGI HASIL KALI RUANG METRIK KERUCUT”, EKSAKTA: Berkala Ilmiah Bidang MIPA, 19(1), pp. 63-67. doi: 10.24036/eksakta/vol19-iss1/128.

[139] Dinata, M. and Soehardi, F. (2018) "Factor Analysis of Physics Chemistry Waters that Affects Damage Safety Cliff on the Outskirts of River Siak", EKSAKTA: Berkala Ilmiah Bidang MIPA, 19(2), pp. 46-49. doi: 10.24036/eksakta/vol19-iss2/143.

[140] Syafei, N. (2017) “ANALISA FENOMENA KOROSI PELAT PIPA BAJA KARBON API 5L-X65 DALAM LARUTAN 250 ML ASAM ASETAT 
DAN 4750 ML AQUADES PADA KONDISI GAS CO2 DAN H2S JENUH PADA SUHU RUANG", EKSAKTA: Berkala Ilmiah Bidang MIPA, 18(02), pp. 113-120. doi: 10.24036/eksakta/vol18-iss02/63.

[141] Syafei, N. (2018) "Riset Material ANALISA FENOMENA KOROSI PELAT PIPA BAJA KARBON API 5L-X65 DALAM LARUTAN 7900 ML AIR LAUT DAN 100 ML AMONIAK PADA KONDISI GAS CO2 DAN H2S JENUH PADA SUHU RUANG.”, EKSAKTA: Berkala Ilmiah Bidang MIPA, 19(1), pp. 7-13. doi: 10.24036/eksakta/vol19-iss 1/83.

[142] Hidayat, D. (2018) "ANALISIS RESPON PENGONTROL ON-OFF PADA KENDALI UMPAN BALIK SISTEM FISIS ELEKTRONIK", EKSAKTA: Berkala Ilmiah Bidang MIPA, 19(1), pp. 118124. doi: 10.24036/eksakta/vol19-iss1/119.

[143] Samah, S. (2017) "KARAKTERISASI PLASTIK BIODEGRADABEL DARI LDPE-g-MA DAN PATI TANDAN KOSONG SAWIT”, EKSAKTA: Berkala Ilmiah Bidang MIPA, 18(02), pp. 30-38. doi: 10.24036/eksakta/vol18-iss02/48.

[144] Hidayani, T. (2018) “GRAFTING POLIPROPILENA DENGAN MALEAT ANHIDRIDA SEBAGAI PENGIKAT SILANG DENGAN INISIATOR BENZOIL PEROKSIDA", EKSAKTA: Berkala Ilmiah Bidang MIPA, 19(1), pp. 56-62. doi: 10.24036/eksakta/vol19-iss1/127.

[145] Sudrajat, R. (2017) “TINJAUAN TENTANG KETERKAITAN PARAMETER DENGAN MODEL REGRESI MULTIVARIAT PADA KOLAM IKAN TERTUTUP”, EKSAKTA: Berkala Ilmiah Bidang MIPA, 18(02), pp. 158-163. doi: 10.24036/eksakta/vol18-iss02/72.

[146] Hidayat, D. (2017) "IMPLEMENTASI PENGONTROL PID PADA MODEL FISIS ELEKTRONIK", EKSAKTA: Berkala Ilmiah Bidang MIPA, 18(02), pp. 178-185. doi: 10.24036/eksakta/vol18-iss02/75.

[147] Ningsih, S. K. (2017) "SINTESIS DAN KARAKTERISASI NANOPARTIKEL ZnO DOPED Cu2+ MELALUI METODA SOLGEL", EKSAKTA: Berkala Ilmiah Bidang MIPA, 18(02), pp. 39-51. doi: 10.24036/eksakta/vol18-iss02/51.

[148] Susilaningrum, D. (2017) "PEMODELAN REGRESI LOGISTIK PADA FAKTOR YANG MEMPENGARUHI PHBS PADA RUMAH TANGGA PENDERITA TBC DI PESISIR SURABAYA”, EKSAKTA: Berkala Ilmiah Bidang MIPA, 18(02), pp. 121-128. doi: 10.24036/eksakta/vol18-iss02/65.

[149] Samah, S. (2017) "KARAKTERISASI PLASTIK BIODEGRADABEL DARI LDPE-g-MA DAN PATI TANDAN KOSONG SAWIT”, EKSAKTA: Berkala Ilmiah Bidang MIPA, 18(02), pp. 30-38. doi: 10.24036/eksakta/vol18-iss02/48.

[150] Setianto S. ANALISA KUANTITATIF CAMPURAN SENYAWA OKSIDA SEBAGAI DASAR IDENTIFIKASI KANDUNGAN BAHAN SUMBER DAYA ALAM Studi Kasus : Kandungan Mineral pada Pasir Besi di Pesisir Pantai Selatan, Jawa Barat. EKSAKTA [Internet]. 30Nov.2017 [cited 11May2019];18(02):173-7. Available from: http://eksakta.ppj.unp.ac.id/index.php/eksakta/article/view/74 


\section{AUTOBIOGRAFI}

Nama saya Novia Anggraini, lahir di Payakumbuh, 19 Maret 1999. Saya anak pertama dari dua bersaudara, dari pasangan Azwir Sagita dan Alnita Safni. Saudara perempuan saya bernama Aina Fadilla yang kini sebagai seorang siswi kelas sepuluh di SMA N 1 Lubuk Basung. Saat ini saya dan keluarga tinggal di Jorong Koto Malintang, Nagari Sariak Laweh, Kec. Akabiluru, Kab.50 Kota. Sekarang saya seorang mahasiswa di Universitas Negeri Padang, jurusan Kimia, program studi Pendidikan Kimia. Jenjang pendidikan yang pernah saya tempuh yaitu, SD N 06 Sariak Laweh tahun masuk 2005, SMP N 1 Lubuk Basung tahun 2011, selepas lulus SMP di tahun 2014 saya menyambung ke sekolah menengah pertana di SMA N 1 Lubuk Basung tahun lulus 2017. Sejak kecil saya sudah bercita-cita menjadi seorang guru, terutama menjadi guru kimia. Pada saat SMP dan SMA saya sudah aktif mengikuti lomba dalam bidang akademik, seperti lomba matematika, lomba biologi, dan lomba kimia. Saya ingin memiliki kualitas guru kimia di sekolah tempat saya mengajar nanti layaknya dosen yang membawa peserta didik saya menjuarai lomba-lomba. 


\section{Studi Katalitik Herbal}

\section{Ekstrak}

\section{Daun Salam Sebagai}

Bahan Aktif

by Novia Anggraini

Submission date: 15-Apr-2019 02:46PM (UTC+0700)

Submission ID: 1112720999

File name: NOVIA_ANGGRAINI.pdf (490.02K)

Word count: 1899

Character count: 11449 


\title{
STUDI KATALITIK HERBAL REBUSAN DAUN SALAM SEBAGAI BAHAN AKTIF MENURUNKAN TEKANAN DARAH TINGGI
}

\author{
Program Studi Pendidikan Kimia FMIPA Universitas Negeri Padang \\ II. Prof. Dr. Hamka Air Tawar Padang. Sumatera Barat \\ e-mail: noviaanggrainil $903 \alpha$ gmail com
}

\begin{abstract}
Abstrak
Studi ini bertujuan untuk membuat ekstrak pada tumbuhan daun salam untuk menurunkan tekanan darah tinggi atau hipertensi. Metode yang digunakan adalah eksperimen dan uji aktivitas katalitik secara langsung. Tahapan pertama dilakukan dengan pembuatan ekstrak daun salam. Uji aktivitas langsung dengan variasi volume air ekstrak daun salam yang diminum selama tujuh hari. Hasil eksperimen membuktikan bahwa ckstrak daun salam dapat menurunkan tekanan darah tinggi. Kondisi optimal terhadap ckstrak daun salam tercapai pada $90 \mathrm{ml}$ dengan tekanan darah $130 \mathrm{mmHg}$. Diduga penurunan tekanan darah ini karena aktivitas katalitik ckstrak daun salam terhadap penurunan kolesterol, sehingga flavonoid, saponin dan tannin dapat digunakan sebagai penurunan tekanan darah tinggi atau hipertensi.
\end{abstract}

Keywords: katalitik, rebusan, daun salam, tekanan darah tingei, flavonoid, saponin, tanin

1. PENDAHULUAN

Reaksi katalitik adalah reaksi kimia yang melibatkan katalis dalam reaksinya. Reaksi kimia yang melibatkan katalis dalam reaksinya dapat mempercepat terjadinya reaksi namun katalis tidak ikut bereaksi. Suatu reaksi sangat penting dalam kehidupan. Jika suatu reaksi kimia tidak berjalan sesuai maka akan terjadi pembusukan. Reaksi kimia juga terjadi ditubuh manusia, hewan dan tumbuhan, mulai dari reaksi kimia yang sederhana sampai reaksi kimia yang kompleks, reaksi kimia dapat terjadi cepat atau lambat sesuai reaktan yang direaksikan. Jika suatu reaksi kimia lambat maka dapat ditambahkan katalis.

Reaksi katalitik dapat berjalan secara reversible dan irrversibel. Reaksi yang mengalami reversible dapat berbalik arah, sedangkan reaksi irreversible tidak dapat berbalik arah. Adapun factor yang menjadi suatu reaksi dapat mengalami reversible, diantaranya reaktan yang digunakan sesuai dan spesifik. Contoh nya reaksi kesetimbangan. Namun, kebanyakan reaksi kimia jarang yang mengalami reaksi reversible, karena suatu reaksi kimia akan mengalami pebuhan kimia. Ciri-ciri 
Studi Katalitik Herbal Rebusan Daun Salam

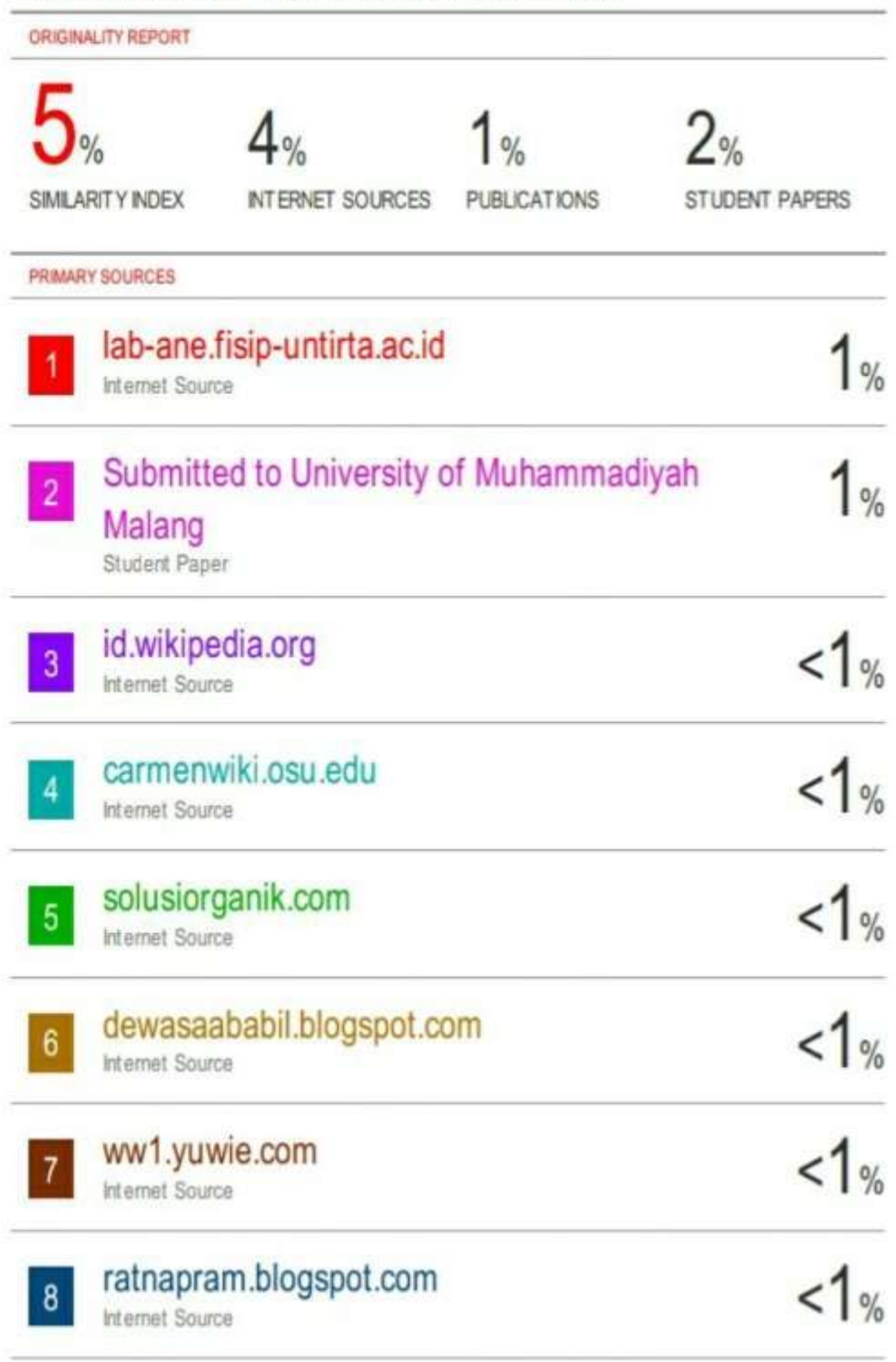

penyakitherpes8.blogspot.com 
Intemet Source

$<1 \%$

$\begin{array}{lll}\text { Exclude quotes } & \text { On Exclude matches } & <3 \text { words } \\ \text { Exclude bibliography } & \text { On } & \end{array}$




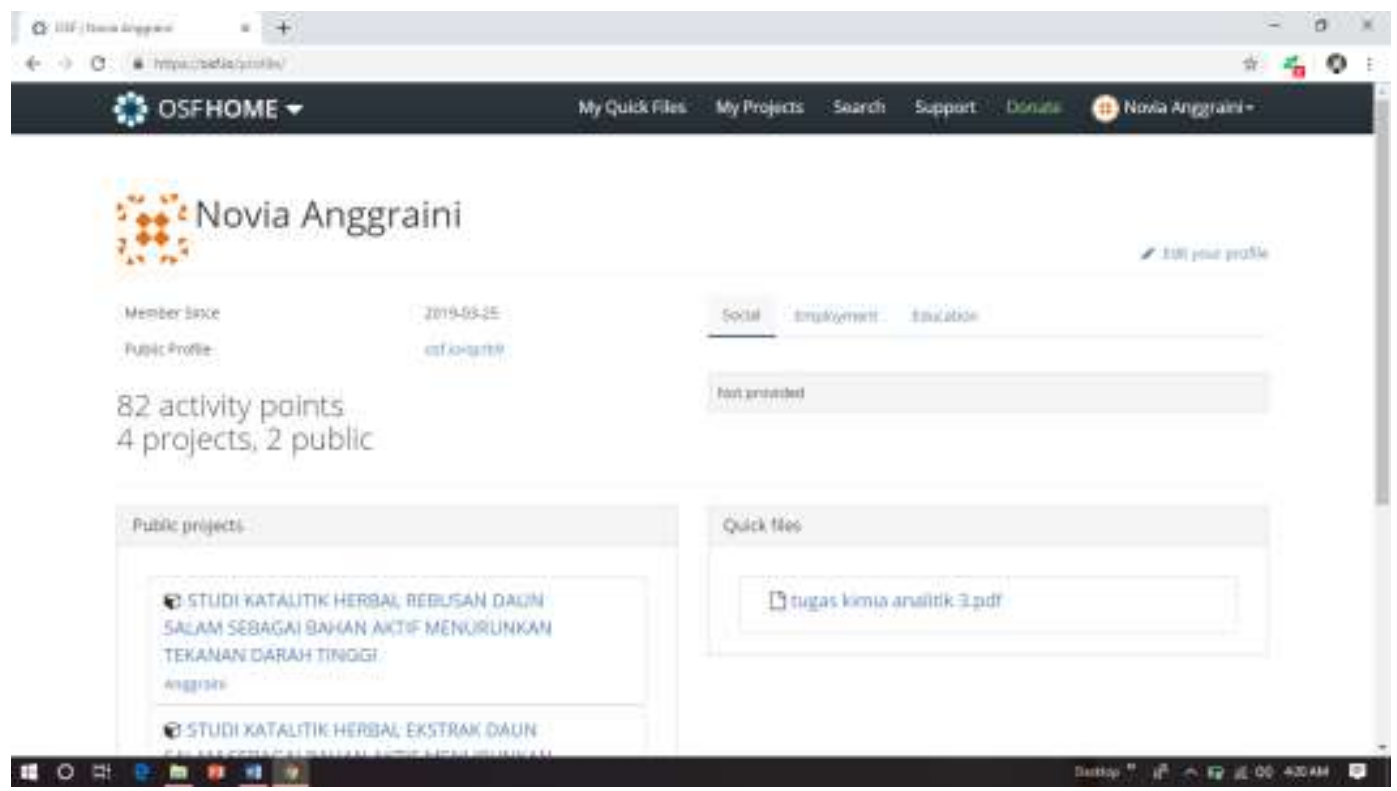

